\title{
Bortezomib-Based Regimens and Plasma Cell Leukemia
}

\author{
Bortezomib Bazlı Rejimler ve Plazma Hücreli Lösemi
}

(D) Ali Zahit Bolaman

Adnan Menderes University Faculty of Medicine, Department of Hematology, Aydın, Turkey

\section{To the Editor,}

Plasma cell leukemia (PCL) is defined by the presence of more than 20\% plasma cells and absolute plasma cell count of greater than $2 \times 109 / \mathrm{L}$ in peripheral blood. PCL can be primary (pPCL; de novo) or secondary (sPCL; leukemic transformation of multiple myeloma). The prognosis of sPLC is worse than that of $\mathrm{PPCL}$. There is no standard approach to PCL. Previous retrospective studies have shown that bortezomib is beneficial in these patients. Stem cell transplantation is useful in treatment for PCL outcomes [1].

I read with interest the article entitled "Bortezomib-based regimens improve the outcome of patients with primary or secondary plasma cell leukemia: a retrospective cohort study," recently published in this journal [2]. The authors retrospectively reported the treatment results of 56 patients with PCL. They administered non-bortezomib regimens to 4 of $15 \mathrm{pPCL}$ patients and to 14 of $42 \mathrm{sPCL}$ patients. The authors suggested that bortezomib regimens are effective in cases of PCL. The number of patients in the groups of the study were not equal. The small number of patients was a limitation of the study, which also reduced the power of the study in terms of statistical analysis. Furthermore, only 2 of $15 \mathrm{pPCL}$ patients received stem cell transplantation. This may have caused patients to be incomplete in their treatment. Progression-free survival (PFS) was 8.3 months in the group receiving bortezomib and 1.2 months in the nonbortezomib group with $\mathrm{pPCL}$ in this study. Lawless et al. showed that transplantation was an effective treatment in 756 patients with $\mathrm{pPCL}$ as the median PFS in transplanted pPCL patients was found to be 14.3 months [3]. Therefore, stem cell transplantation should be preferred in PCL patients. Gowda et al. [4] used proteasome inhibitors or immunomodulatory drugs alone or in combination with steroids before stem cell transplantation in pPCL patients. Allogeneic stem cell transplantation should be preferred for patients under the age of 50 years [4].
The effect of bortezomib on PCL has been known for a long time, as in all patients who are candidates for stem cell transplantation. Today, using drugs other than bortezomib may be an effective treatment option, and adding monoclonal antibodies and venetoclax to therapy may improve outcomes, especially in high-risk patients with PCL $[5,6]$.

Keywords: Bortezomib, Plasma cell leukemia, Treatment

Anahtar Sözcükler: Bortezomib, Plazma hücreli lösemi, Tedavi

Financial Disclosure: The author declared that this study received no financial support.

\section{References}

1. Gavriatopoulou M, Musto P, Caers J, Merlini G, Kastritis E, van de Donk N, Gay F, Hegenbart U, Hajek R, Zweegman S, Bruno B, Straka C, Dimopoulos MA, Einsele H, Boccadoro M, Sonneveld P, Engelhardt M, Terpos E. European Myeloma Network recommendations on diagnosis and management of patients with rare plasma cell dyscrasias. Leukemia 2018;32:1883-1898.

2. Wang $H_{\text {, Zhou }}$, Zhang Z, Geng $C$, Chen W. Bortezomib-based regimens improve the outcome of patients with primary or secondary plasma cell leukemia: a retrospective cohort study. Turk J Hematol 2020;37:91-97.

3. Lawless $S$, lacobelli $S$, Knelange $N$, Chevallier P, Blaise D, Milpied NJ, Foà R, Cornelissen JJ, Lioure B, Potter V, Poire X, Petersen EJ, Collin MP, Lenhoff S, Snowden J, Santarone S, Wilson K, Guimaraes JE, Dreger P, Schipperus MR, Morris C, Schönland S, Yakoub-Agha I, Garderet L, Nicolaus K. Results of autologous and allogeneic transplantation in patients with primary plasma cell leukemia: a large retrospective analysis of the Chronic Malignancies Working Party of the EBMT. Blood 2018;132(Suppl 1):3425 (abstract).

4. Gowda L, Shah M, Badar I, Bashir Q, Shah N, Patel K, Kanagal-Shamanna R, Mehta R, Weber DM, Lee HC, Manasanch EE, Shah A, Thomas SK, Parmar $S$, Nieto $Y$, Orlowski RZ, Champlin R, Qazilbash MH. Primary plasma cell leukemia: autologous stem cell transplant in an era of novel induction drugs. Bone Marrow Transplant 2019;54:1089-1910.

5. Nolghranyan $S$, Singh AP, Schinke C. The combination of venetoclax daratumumab and dexamethasone for the treatment of refractory primary plasma cell leukemia. Am J Hematol 2020;95:E34-E35.

6. Horisawa $Y$, Kondo $T$, Hishizawa $M$, Yamashita $K$, Takaori-Kondo A. A case of allogeneic hematopoietic stem cell transplantation for primary plasma cell leukemia after treatment with daratumumab. Ann Hematol 2020;99:2699-2701.

๑Copyright 2021 by Turkish Society of Hematology

Turkish Journal of Hematology, Published by Galenos Publishing House 